\title{
Employment in Croatia: Insights into the past and the future
}

\author{
Veselin Draskovic \\ University of Social Sciences, Poland; \\ University of Montenegro, Montenegro \\ veso-mimo@t-com.me \\ ORCID 0000-0003-3968-422X
}

\section{Justin Pupavac}

University of Rijeka, Croatia,

Faculty of Tourism and Hospitality Management

Opatija

pupavacjustin@gmail.com

\section{Milica Delibasic}

Mediterranean University,

Faculty of Business Studies,

Podgorica, Montenegro

23.mildel@gmail.com

\section{Leszek Kołtun}

Institute of Security Sciences, Higher School of Criminology and Penitentiary

Science in $W$ arsaw, $W$ arsaw, Poland

leszek.koltun@wskip.edu.pl

ORCID 0000-0001-6217-4303

Abstract. The aim of this paper is to explore the relationship between the movement of GDP and the employment in Croatia (CRO). The objective of this paper is to give an estimate on the number of employees needed in the following period as well as possibilities to find workers, having in mind the negative demographic trends. The hypothesis indicates that there is a significant correlation between GDP movement and total employment as well as weak but positive correlation between GDP movement and unemployment.

Received: January, 2020 1st Revision: December, 2020

Accepted: March, 2021 $8330.2021 / 14-1 / 8$ Numerous scientific methods, among which are the methods of analysis and synthesis, the method of descriptive statistics and the method of mathematical modelling, have been applied to achieve the goal of this research. The main result of this work leads to the 
conclusion that human resources will become the limiting factor for economic growth in the future. Therefore, economic policy measures should be taken in order to change the detected negative trends while forming the demographic capital of the country.

Keywords: employment, labour, labour market, demographic capital, Croatia.

JEL Classification: E24, J23, M51

\section{INTRODUCTION}

In a contemporary society, it is very important to establish a proportional division of labour by different production activities within the area, branches and groups, i.e., a certain proportion between the quantity and the type of work on the one hand, and the scope and structure of social needs on the other. In organized production of goods, there is a law of supply and demand which determines what will be produced, how it will be produced (to which production the work will be directed) and how much working time will be necessary for the production of certain goods and services (Pupavac et al., 2020, pp 8-9). The labour market has established relations between supply (employees) and demand for labour (employers). The total labour supply in a company depends on at least four factors: the number of inhabitants, the participation of workers in the total population, the average number of working hours per week or year and the quality, quantity and qualification of work. Labour market is an important segment of any economy and it is connected with the capital market, the market of goods and services, as well as all other economic entities (government, companies and households). Unlike the capital market and the market of goods and services, labour market is subject to far greater fluctuations, restrictions and regulation (Bilbao-Ubillos et al., 2018), which is justified by its impact on business activity due to the labour supply and HRM processes efficiency (Bilan et al., 2020a) as well as reasons for decent quality of life maintaining via the employment and income policy (Karamanis et al., 2018; Mishchuk et al., 2020), including structural changes in economy (Maris, 2019).

Governments all around the world are facing numerous challenges at the labour market. Insufficient number of workers, unemployment, underemployment, labour skills mismatches and discrimination (gender, racial) at the labour market are just some of the challenges faced by governments, regardless of their country's level of development. For example, Germany (Deastatis - German State Statistical Office, 2017) as one of the most developed countries in the world simultaneously shows the need for additional labour, unemployment of about 1.6 million and underemployment of the existing 5.1 million workers. Parttime employees are especially considered to be underutilized at work. There are also 1.4 million employees working overtime. According to the same survey, $5.9 \%$ of all the employees expressed a desire to work more. In this context, the innovative practice of the European Union countries in the part of stimulating human factors is significant.

Institutions of Croatian labour market are increasingly approaching the markets of developed Western economies (Popovic et al., 2020). In functional terms, Croatian labour market as an integral part of the European labour market AND is strongly influenced by European integration and globalization (Logarusic \& Raguz Krstic, 2019). Internal factors that determine the relations at the national labour market are negative demographic trends (Becic et al., 2019) and deindustrialization of the economy which is peculiar to many post-socialist countries. Both of these factors had a negative impact on both aggregate supply and aggregate labour demand. The deindustrialization (Penava \& Druzic, 2014) of the national economy had a decisive impact on the developing imbalances at the domestic labour market which is resulting in a significant 
increase in unemployment. All this should be viewed through the prism of the impact of labour potentials on the competitiveness of any economy.

As one of the four basic macroeconomic goals (the so-called "magic quadrangle") is to achieve full employment, this scientific discussion explores the relationship between GDP growth and employment growth (ECB, 2017) in Croatia during the period from 1967 to 2019. According to the trends, a forecast of employment by 2050 will be presented, the main problems related to the future workforce will be detected and appropriate solutions will be offered.

\section{THEORETICAL APPROACH}

The labour market is a complex and significant area of the economic and social system, because it valorizes the value of labour force, determines working conditions, size of the wage, level and guarantees of employment, dynamics and structure of employment (branch, demographic, professional), social division of labour, labour mobility, unemployment dynamics, etc. In Western economic theories of the labour market, four conceptions of the analysis of its functioning stand out. The basis of the first concept, which is represented by the representatives of the neoclassical school and the theory of supply, is the understanding that the labour market, like all other markets, functions on the basis of price equilibrium. This means that the price of labour is the basic market regulator: wages regulate supply and demand relations and support their balance. Investing in the knowledge, education and qualification of staff can be compared to investments in machinery and equipment. These dependencies are appropriate for labour market equilibrium in general, without taking into account the impact of discrimination by specific reasons (Bilan et al., 2020b; Stavytskyy et al., 2020). Individuals invest in qualifications until the rate of return on those investments begins to decline. According to the neoclassical conception, the price of labour reacts elastically to the needs of the market (supply and demand), and there is no unemployment when there is a balance on the labour market. In general, according to neoclassical theory, unemployment is caused by supply-side factors (Bierens \& Broersma, 1993).

Unlike neoclassicists, Keynesians and monetarists see the labour market as a phenomenon of constant imbalance. Labour has a fixed price (wage) that rarely changes. Since the price does not affect the establishment of balance in the labour market, this role is played by the state, which through the reduction or increase of aggregate demand (volume of production) acts to establish balance. Monetarists start from the same idea, but introduce the term of "natural” level of unemployment, which reflects the structural characteristics of the labour market and makes labour prices inelastic, which creates obstacles to the normal functioning of the market, deepens its imbalance and unemployment itself. According to post-Keynesian theory, the labour market is dominated by demand in both the short and medium term (Stockhammer et al., 2014). Institutionalists pay the greatest attention to the analysis of the professional and branch structure of the labour force and the appropriate level of wages. Finally, let us remember that the Marxist conception saw the labour market very specific. Labour was considered as a good that creates value in the process of production. Since labour is a subjective factor of production, it was considered that it can actively influence the supply-demand relationship, i.e. its market price.

None of the above concepts provides a complete and appropriate picture of how the mechanism of the labour market functions, which is considered as a specific market in many ways. These specifics arise primarily from demographic, socio-psychological, ethnic, migration and other factors, which, in addition to economic ones, affect the dynamics of employment. Most researchers divide the labour market into two segments: primary (independent and subordinate) and secondary jobs. Primary independent jobs are held by highly educated specialists, managers, administrative and highly qualified workers. The primary subordinate positions are occupied by technicians, administrative assistants and workers with secondary 
qualifications. Secondary jobs are occupied by service (simple services) and unskilled workers. In this context, labour mobility (cross-border and inter-professional mobility) is very important. State regulation is a significant factor influencing the labour market. In practice, it is manifested in several direct ways (programs for stimulating employment growth in the public sector, programs for preparation and reorientation of the labour force, programs for social protection of the unemployed) and indirect ways (tax, monetary and depreciation policy of the government, labour law). A special place in the system of labour market regulation is occupied by the labour exchange as a special institution that performs an intermediary function in the labour market. Most labour exchanges have a state character, but in practice a large number of private intermediary companies also operate. Labour exchanges register the unemployed and vacancies, look for suitable employment, study the labour market situation and provide information about it, perform tests and professional preparation of the unemployed, etc.

\section{DATA AND RESEARCH METHODOLOGY}

Achieving full employment is one of the fundamental goals of each national economy. This goal is directly related to the realization of potential or maximum possible GDP (Okun, 1962). Increase of the GDP is usually accompanied with higher number of employees and the other way around. Trends in GDP and the number of employees in Croatia from 1967 to 2019 are shown in Table 1.

Table 1

GDP trends, number of employees and unemployed in Croatia, 1967-2019

\begin{tabular}{|c|c|c|c|c|c|}
\hline Year & $\begin{array}{c}\text { GDP, fixed prices } \\
\text { in } 1990 \text { in million } \\
\text { HRK }\end{array}$ & Employment (000) & $\begin{array}{l}\text { Calculation of } \\
\text { GDP by including } \\
\text { the number of } \\
\text { employees in the } \\
\text { linear trend } \\
\text { equation * }\end{array}$ & $\varepsilon t$ & $\begin{array}{c}\text { Unemployment } \\
(000)\end{array}$ \\
\hline 1967 & 139359,06 & 878 & 145878,42 & $-6519,36$ & 58 \\
\hline 1968 & 142692,20 & 882 & 146905,98 & $-4213,78$ & 64 \\
\hline 1969 & 155202,24 & 895 & 150245,55 & 4956,69 & 57 \\
\hline 1970 & 164181,18 & 928 & 158722,92 & 5458,26 & 47 \\
\hline 1971 & 183443,57 & 964 & 167970,96 & 15472,61 & 42 \\
\hline 1972 & 187481,44 & 1005 & 178503,45 & 8977,99 & 47 \\
\hline 1973 & 192305,01 & 1018 & 181843,02 & 10461,99 & 54 \\
\hline 1974 & 218272,60 & 1055 & 191347,95 & 26924,65 & 55 \\
\hline 1975 & 217393,53 & 1109 & 205220,01 & 12173,52 & 67 \\
\hline 1976 & 224400,14 & 1143 & 213954,27 & 10445,87 & 83 \\
\hline 1977 & 241634,62 & 1209 & 230909,01 & 10725,61 & 88 \\
\hline 1978 & 255968,57 & 1262 & 244524,18 & 11444,39 & 83 \\
\hline 1979 & 270873,52 & 1315 & 258139,35 & 12734,17 & 77 \\
\hline 1980 & 277591,22 & 1357 & 268928,73 & 8662,49 & 78 \\
\hline 1981 & 282220,66 & 1396 & 278947,44 & 3273,22 & 86 \\
\hline 1982 & 287810,10 & 1419 & 284855,91 & 2954,19 & 99 \\
\hline 1983 & 290761,67 & 1434 & 288709,26 & 2052,41 & 108 \\
\hline 1984 & 298659,81 & 1457 & 294617,73 & 4042,08 & 114 \\
\hline 1985 & 292006,43 & 1489 & 302838,21 & $-10831,78$ & 120 \\
\hline 1986 & 302134,80 & 1531 & 313627,59 & $-11492,79$ & 123 \\
\hline 1987 & 302525,04 & 1563 & 321848,07 & $-19323,03$ & 123 \\
\hline 1988 & 300807,94 & 1559 & 320820,51 & $-20012,57$ & 135 \\
\hline 1989 & 297392,40 & 1556 & 320049,84 & $-22657,44$ & 140 \\
\hline 1990 & 276277,54 & 1509 & 307976,01 & $-31698,47$ & 161 \\
\hline 1991 & 217982,98 & 1378 & 274323,42 & $-56340,44$ & 254 \\
\hline
\end{tabular}




\begin{tabular}{|c|c|c|c|c|c|}
\hline 1992 & 192478,97 & 1212 & 231679,68 & $-39200,71$ & 267 \\
\hline 1993 & 177080,65 & 1190 & 226028,10 & $-48947,45$ & 251 \\
\hline 1994 & 187528,41 & 1163 & 219092,07 & $-31563,66$ & 243 \\
\hline 1995 & 200280,34 & 1196 & 227569,44 & $-27289,10$ & 241 \\
\hline 1996 & 211968,42 & 1195 & 227312,55 & $-15344,13$ & 261 \\
\hline 1997 & 226346,67 & 1188 & 225514,32 & 832,35 & 278 \\
\hline 1998 & 231158,76 & 1272 & 247093,08 & $-15934,32$ & 288 \\
\hline 1999 & 227685,12 & 1263 & 244781,07 & $-17095,95$ & 322 \\
\hline 2000 & 234589,65 & 1341 & 264818,49 & $-30228,84$ & 358 \\
\hline 2001 & 243585,96 & 1348 & 266616,72 & $-23030,76$ & 380 \\
\hline 2002 & 256841,78 & 1359 & 269442,51 & $-12600,73$ & 390 \\
\hline 2003 & 269575,02 & 1393 & 278176,77 & $-8601,75$ & 330 \\
\hline 2004 & 281031,02 & 1409 & 282287,01 & $-1255,99$ & 310 \\
\hline 2005 & 292859,83 & 1420 & 285112,80 & 7747,03 & 309 \\
\hline 2006 & 306739,80 & 1468 & 297443,52 & 9296,28 & 292 \\
\hline 2007 & 323522,76 & 1517 & 310031,13 & 13491,63 & 265 \\
\hline 2008 & 331155,41 & 1555 & 319792,95 & 11362,46 & 256 \\
\hline 2009 & 306981,06 & 1449 & 292562,61 & 14418,45 & 263 \\
\hline 2010 & 302376,34 & 1432 & 288195,48 & 14180,86 & 302 \\
\hline 2011 & 301469,22 & 1411 & 282800,79 & 18668,43 & 305 \\
\hline 2012 & 294535,42 & 1395 & 278690,55 & 15844,87 & 324 \\
\hline 2013 & 293062,75 & 1364 & 270726,96 & 22335,79 & 345 \\
\hline 2014 & 292769,68 & 1342 & 265075,38 & 27694,30 & 328 \\
\hline 2015 & 299796,16 & 1357 & 268928,73 & 30867,43 & 286 \\
\hline 2016 & 310289,02 & 1390 & 277406,10 & 32882,92 & 242 \\
\hline 2017 & 319907,98 & 1407 & 281773,23 & 38134,75 & 194 \\
\hline 2018 & 328545,50 & 1498 & 305150,22 & 23395,28 & 154 \\
\hline 2019 & 338073,32 & 1540 & 315939,60 & 22133,72 & 129 \\
\hline
\end{tabular}

Source: Croatian bureau of statistics, SLJH, different years and author's calculation

* The data in table 1 in columns 4 and 5 are the result of their own calculation based on the linear regression model cf. infra chapter 4

The collected secondary data on GDP, total employment and unemployment rate in the

Croatia refer to the period from 1967 to 2019. Data were collected from the Statistical Yearbooks of the Croatia for different years. Real growth rates on annual level were used to calculate part of necessary data about GDP movement during constant prices for the reference year 1990. Descriptive statistics were used to obtain a clear idea of the observed variables (GDP, employment, unemployment), their arithmetic means, standard deviations and variance measures. Correlation analysis was used to determine the direction and degree of correlation between GDP on the one hand and employment and unemployment on the other. After a positive and strong correlation between GDP and employment was established, a regression analysis was carried out. Regression analysis analytically expressed the relationship between GDP and total employment in the form of a linear, quadratic and exponential model. Given that all three models showed high statistical reliability, the calculation of GDP by years was conducted by including the number of employees in the linear trend equation. This enabled to compare the actual value with projected value for the observed period from 1967 to 2019. The obtained regression model was also used to estimate the required number of employees in the economy of the Croatia by 2050, assuming GDP growth at an average annual growth rate of $2 \%$. Subsequently an analysis of demographic trends was conducted. These trends were used to make an estimate of the total population of the Croatia in the future. This projection was made to compare the population and the required number of employees in 2050 and accordingly get an answer to the question: Will human resources become a limiting factor of economic growth? The answer to this question is extremely important for all countries in the region not only because of the connection of their 
economies and similar economic structure but also because of the fact that Slavic peoples have a decreasing share in the population structure (Druzic, 2004).

\section{RESEARCH RESULTS AND DISCUSSION}

According to the data from table 1, short descriptive analysis of GDP movement and number of employees (NE) in the Croatia for period between 1967-2019 was made (cf. table 2).

Table 2

Descriptive statistics of GDP and number of employees in the Croatia, 1967-2019

\begin{tabular}{|l|c|c|}
\hline & GDP & NE \\
\hline MEAN case 1-53 & 256634,21 & 1309 \\
\hline MEDIAN case 1-53 & 276277,54 & 1359 \\
\hline SD case 1-53 & 53630,65 & 192 \\
\hline VALID_N case 1-53 & 53 & 53 \\
\hline MIN case 1-53 & 139359,06 & 1563 \\
\hline MAX case 1-53 & 338073,32 & 1195 \\
\hline 25th\% case 1-53 & 217982,98 & 1434 \\
\hline 75th\% case 1-53 & 299796,16 & \\
\hline
\end{tabular}

Source: own compilation

Based on the data in table 2 and according to fixed prices in 1990, average GDP in the observed period was 256.6 billion HRK (SD=53,6). The lowest GDP was 139.3 billion HRK in 1967 and the highest one was in 2019 when it reached 339, 07 billion HRK. During the observed period, GDP increased by 2.43 times or $143 \%$. The highest GDP in the pre-transition period was realized in 1987 in the amount of 302.5 billion HRK, which points to the conclusion that in the last three decades, real GDP in Croatia has increased by only 11.7\%. Real GDP in the observed period from 1967 to 2019 grew at an average annual growth rate of $1.68 \%$. The average number of employees during the observed period was 1.3 million $(\mathrm{SD}=0.19)$. The lowest number of employees was 878,000 in 1967. On the other hand, the largest number of employees was 1.56 million and it was realized in 1987. In 2019, number of employees almost reached 1.54 million, and in 2020 it would have been exceeded if it were not for crises caused by the Covid-19 virus pandemic. During the observed period from 1967 to 2019, the number of employees in the Croatia grew at an average annual rate of $1.06 \%$. The number of employees in 2019 was $75.4 \%$ higher than in 1967 . Based on this, it can be concluded that in the observed period in the Croatia GDP growth of $2 \%$ was accompanied by an increase in the number of employees of $0.896 \%$. More precisely, the average GDP growth of $1 \%$ is followed by an average increase in the number of employees of $0.61 \%$. According to the data from table 1 , short descriptive statistical analysis of unemployment in the Croatia for period between 1967 - 2019 was made (cf. table 3).

Table 3

Descriptive statistics of unemployment in the Croatia, 1967-2019

\begin{tabular}{|l|c|}
\hline & UN \\
\hline MEAN case 1-53 & 194 \\
\hline MEDIAN case 1-53 & 194 \\
\hline SD case 1-53 & 109 \\
\hline VALID_N case 1-53 & 53 \\
\hline SUM case 1-53 10276 \\
\hline MIN case 1-53 & 42 \\
\hline MAX case 1-53 & 390 \\
\hline 25th\% case 1-53 & 86 \\
\hline 75th\% case $1-53$ & 288 \\
\hline
\end{tabular}

Source: own compilation 
During the period between 1967 and 2019, an average of 194,000 people was looking for a job annually $(\mathrm{SD}=109)$. The lowest unemployment rate was recorded in 1971 when only 42,000 people was looking for a job while the highest unemployment rate was recorded in 2002 when that number was 390,000. Even during the year with lowest number of unemployed people demand for work was higher than a supply which further confirms one of the basic specifics of the labour market: There is almost never a shortage of excess supply in the labour market - when there is no unemployment. The calculated coefficient of quartile deviation is $54.01 \%$. The first quarter (quartile) consists of years in which the average annual unemployment was less than 86 thousand, and the last quarter (quartile) of those years in which the average annual unemployment was more than 288,000 . During the remaining years, the average annual unemployment is ranged from 86,000 to 288,000 . The calculated median value $(\mathrm{M}=194)$ shows that in the first half of the observed period the average number of unemployed was less than 194,000 and in the second half higher than 194,000. Large values of standard deviation, i.e. large deviations from the arithmetic mean, also testify to a large degree of variability. The average deviation of the average number of unemployed is SD $=109$ or $55.91 \%$ (coefficient of variation).

Unemployment causes many negative consequences, such as: social exclusion, poverty, demographic crisis, brain drain, grey economy, deteriorating labour conditions, psychosocial losses, etc. Therefore, the governments of countries with high unemployment rate implement a number of passive and active measures in the fight against it. Passive measures reflect the social role of the country, mainly addressing the consequences of unemployment, protecting and improving the situation of the most vulnerable part of the population in order to make it easier to cope with unemployment. Active employment policy measures or active labour market policies aim to reconcile supply and demand in the labour market. Active labour market policy measures concern the improvement of the qualification structure of the labour provider, employment mediation and direct creation of jobs. Based on the data in Table 1, a correlation analysis has been made (cf. table 4). Analysis confirmed the existence of a strong correlation between GDP and total employment $(\mathrm{r}=$ $0,91 ; \mathrm{p}<0,05)$, but also the existence of a weak and positive link between GDP and unemployment $(\mathrm{r}=$ $0,29 ; \mathrm{p}<0,05)$.

Table 4

Correlation analysis between GDP, total employment and unemployment in the Croatia, 1967-2019

\begin{tabular}{|c|c|c|c|c|c|}
\hline \multicolumn{6}{|c|}{$\begin{array}{l}\text { Correlations Marked correlations are significant at } \mathrm{p}<, 05000 \mathrm{~N}=53 \\
\text { (Casewise deletion of missing data) }\end{array}$} \\
\hline & Means & Std.Dev. & GDP & NE & NU \\
\hline GDP & 256634,2 & 53630,66 & 1,000000 & 0,919331 & 0,290807 \\
\hline $\mathrm{NE}$ & 1309,2 & 191,93 & 0,919331 & 1,000000 & 0,393391 \\
\hline NU & 193,9 & 108,86 & 0,290807 & 0,393391 & 1,000000 \\
\hline
\end{tabular}

Source: own compilation

The existence of strong and positive correlation $(\mathrm{r}=0,91 ; \mathrm{p}<0,05)$ between GDP and total employment in the Croatia gives the right for the relationship between these phenomena to be analyzed in the form of appropriate regression models (cf. Figure 1). 

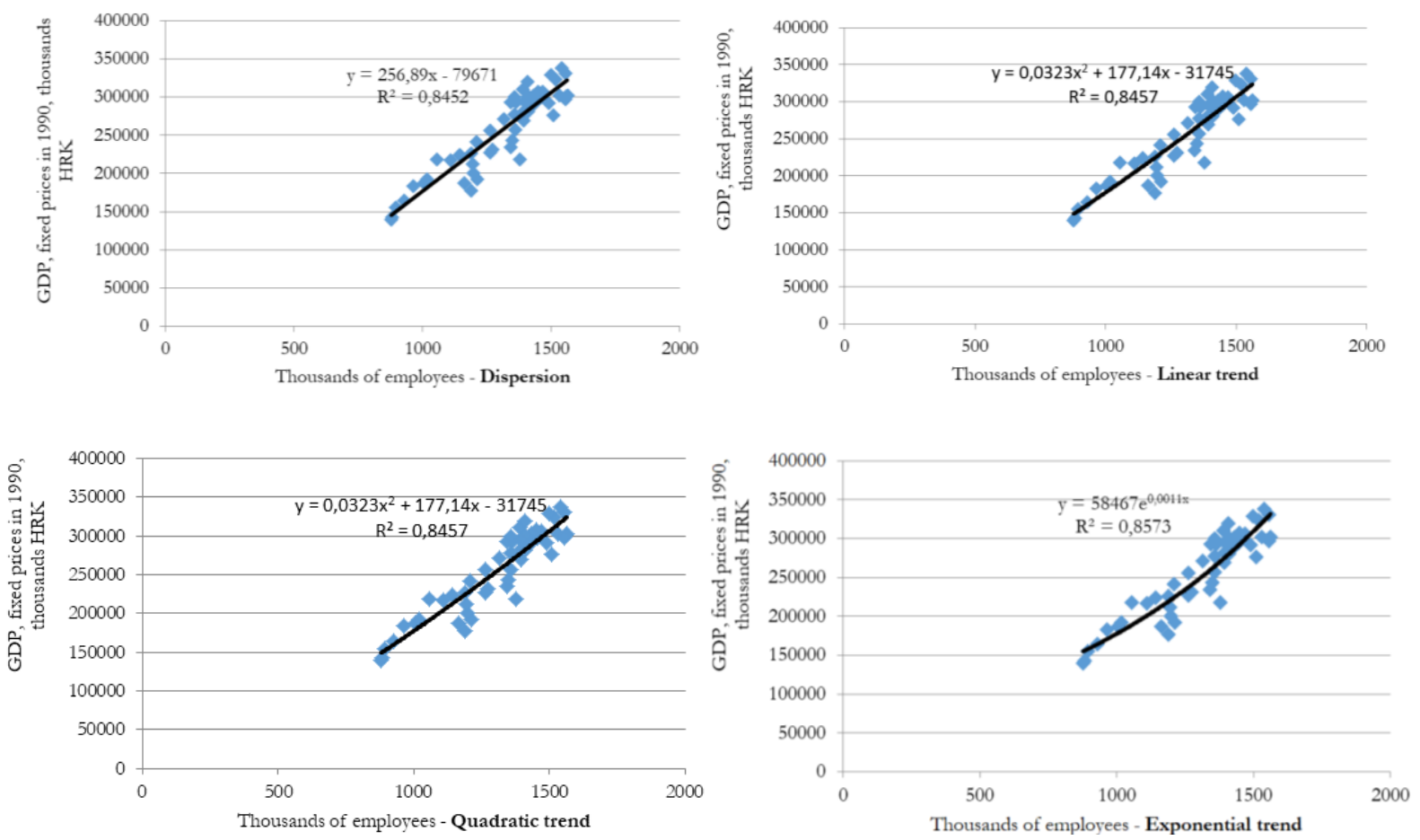

Figure 1. Employment and GDP in Croatia (1967-2019):

Dispersion, linear trend, quadratic trend and exponential trend

Source: own

Linear model: $\mathrm{Y}=256,89 \mathrm{X}-79671\left(\mathrm{R}^{2}=0,8457\right)$

Quadratic model: $\mathrm{Y}=0,0323 \mathrm{X}^{2}+177,14 \mathrm{X}-31745\left(\mathrm{R}^{2}=0,8452\right)$

Exponential model: $58467 \mathrm{e}^{0,0011 \times}\left(\mathrm{R}^{2}=0,8573\right)$.

As all the three displayed models have almost the same statistical reliability based on the linear model (because of its simplicity), GDP has been calculated over the years by including the number of employees in the linear trend equation (cf. paragraph 1, column 4). Thus, the observed and projected GDP values can be compared. The difference between the observed and projected values was negative for the period from 1985 to 2004 (except 1997), while afterwards that difference was positive. Accordingly, it is possible to conclude that, under the conditions of economic crisis, the difference between the observed and projected GDP values is negative, meaning that in the existing GDP the number of employees should be lower, i.e. that the existing number of employees is greater than actually necessary - the performance of the work is lower. In terms of economic growth, the difference between the observed and projected GDP values is positive, meaning that the number of employees in the existing GDP could also be higher, i.e. that the existing number of employees is less than necessary - the performance of the work is higher.

It can be concluded that structural unemployment affected on positive but weak $(\mathrm{r}=0,29 ; \mathrm{p}<0,05)$ correlation between GDP and unemployment during the observed period. The consequence of changing the economic structure of the transition economy, Croatian economy is one of them, was the growth of unemployment.

With the assumption that, in the following period, GDP will grow at an average annual growth rate of 2\% (between 1967 and 2019, the average growth rate was 1,6\%) the required number of employees to achieve this level of GDP would move as shown in Table 5. 
Estimate of GDP trends and the required number of employees in the Croatia by 2050

\begin{tabular}{|l|c|c|c|}
\hline GDP & $\begin{array}{c}\text { GDP (fixed prices in 1990, } \\
\text { in million HRK) }\end{array}$ & $\begin{array}{c}\text { Required number of } \\
\text { employees (000) }\end{array}$ & $\begin{array}{c}\text { Difference between the required and real } \\
\text { number of persons employed in 2019 } \\
(000)\end{array}$ \\
\hline 2030. & 420351,68 & 1946 & +406 \\
\hline 2040. & 512406,35 & 2305 & +765 \\
\hline 2050. & 624620,48 & 2742 & +1202 \\
\hline
\end{tabular}

Source: own compilation

Based on the data in Table 5, it is clear that the average annual GDP growth would correspond to the growth of the required number of employees with an average annual growth rate of $1,1 \%$ which would increase the number of employees in 2050 by 1,2 million or by $78,05 \%$ compared to 2019 . Accordingly, the question here is: How will the Croatia provide the required number of employees within the next 30 years? This problem is particularly important due to negative demographic developments. The demographic growth observed during the period from 1857 to 1991 (+ 119,3\%) has been reversed (cf. table 6).

Table 6

Population trends in the Croatia

\begin{tabular}{|l|c|c|c|c|c|c|c|c|c|}
\hline Year & 1857 & 1890 & 1910 & 1948 & 1971 & 1991 & 2001 & 2011 & 2020 \\
\hline $\begin{array}{l}\text { Population } \\
(000000)\end{array}$ & 2,181 & 2,854 & 3,460 & 3,779 & 4,426 & 4,784 & 4,284 & 4,284 & 4,105 \\
\hline
\end{tabular}

Source: own compilation

Based on data in table 6 it is clear that during the period between 1987-1991 population of the Croatia was growing stedily. The highest number was recorded in 1991. Afterwards, a negative trend appeared. When we compare population of the country during 2020 and 1991 we can determine that population decrease for $678,999(14.2 \%)$. The annual decrease rate between 1991 and 2020 was -0.526 . If this trend continues in the future, Croatia would have 3.5 million people in 2050 and at the end of the century less than 2.69 million people. It means that in 2050 Croatia would have little bit more than in 1910 and in 2100 little bit more than in 1880. Data on the natural and mechanical movement of the population in the Croatia are supporting such a black scenario.

The natural population increase measured as the difference between the number of births and deaths shows a negative trend in the Croatia. Since 1991, the death rate has exceeded the birth rate. With 1.5 children per woman Croatia belongs to the group of countries with the lowest fertility rate in the world. Croatia is on the 14th place in the rate of population reduction.

Negative rates of natural population growth do not favour the rejuvenation of the Croatian population. An ageing of the population in countries that are not at a high level of economic development is a factor in the economic recession. The Croatia has also recorded some negative migration balance years, i.e. the number of emigrants exceeds the number of immigrants (table 7). 
Table 6

Natural change in population in the Croatia, 2009-2018

\begin{tabular}{|c|c|c|c|c|c|c|c|c|}
\hline \multirow[b]{2}{*}{ Year } & \multirow[b]{2}{*}{$\begin{array}{l}\text { Live } \\
\text { births }\end{array}$} & \multirow[b]{2}{*}{ Deaths } & \multirow[b]{2}{*}{$\begin{array}{l}\text { Natural } \\
\text { increase }\end{array}$} & \multicolumn{3}{|c|}{ Rate per 1000 inhabitants } & \multicolumn{2}{|c|}{ Chain indices } \\
\hline & & & & $\begin{array}{l}\text { Live } \\
\text { births }\end{array}$ & Deaths & $\begin{array}{l}\text { Natural } \\
\text { increase }\end{array}$ & Live births & Deaths \\
\hline 2009 & 44577 & 52414 & -7837 & 10,1 & 11,8 & $-1,8$ & 101,9 & 100,5 \\
\hline 2010 & 43361 & 52096 & -8735 & 9,8 & 11,8 & -2 & 97,3 & 99,4 \\
\hline 2011 & 41197 & 51019 & -9822 & 9,6 & 11,9 & $-2,3$ & 95 & 97,9 \\
\hline 2012 & 41771 & 51710 & -9939 & 9,8 & 12,1 & $-2,3$ & 101,4 & 101,3 \\
\hline 2013 & 39939 & 50386 & -10447 & 9,4 & 11,8 & $-2,5 \square$ & 95,6 & 97,4 \\
\hline 2014 & 39566 & 50839 & -11273 & 9,3 & 12 & $-2,7$ & 99,1 & 100,9 \\
\hline 2015 & 37503 & 54205 & -16702 & 8,9 & 12,9 & -4 & 94,8 & 106,6 \\
\hline 2016 & 37537 & 51542 & -14005 & 9 & 12,3 & $-3,4$ & 100,1 & 95,1 \\
\hline 2017 & 36556 & 53477 & -16921 & 8,9 & 13 & $-4,1$ & 97,4 & 103,8 \\
\hline 2018 & 36945 & 52706 & -15761 & 9 & 12,9 & $-3,9$ & 101,1 & 98,6 \\
\hline
\end{tabular}

Source: authors prepared according to https://www.dzs.hr/Hrv_Eng/publication/2019/07-0101_01_2019.htm

The rate of natural increase is not equal to the difference in the rate of live births and deaths due to data rounding.

Table 7

International migration of population of Croatia, 2011-2018

\begin{tabular}{|l|c|c|c|}
\hline Year & Immigrants & Emigrants & Migration balance \\
\hline 2011. & 8534 & 12699 & -4165 \\
\hline 2012. & 8959 & 12877 & -3918 \\
\hline 2013. & 10378 & 15262 & -4884 \\
\hline 2014. & 10638 & 20858 & -10220 \\
\hline 2015. & 11706 & 29651 & -17945 \\
\hline 2016. & 13985 & 36436 & -22451 \\
\hline 2017. & 15553 & 47352 & -31799 \\
\hline 2018. & 26029 & 39515 & -13486 \\
\hline Ukupno & 105782 & 214650 & -108868 \\
\hline
\end{tabular}

Source: authors prepared according to https://www.dzs.hr/Hrv_Eng/publication/2019/07-0102_01_2019.htm

In only 8 years, 214,650 people moved out of the Croatia. Meanwhile, only 105,782 move in. That gives us negative migration balance of 108,868 people. Iti s particularly concerning that young people and inhabitants of less populated areas are moving out of the country. According to global estimates of International Labour Organization (ILO) there was 164 million immigrant workers out of total 258 million immigrants in 2017. That is 3.5\% of the total population in the world. Number of immigrants in 2017 was 85 million (49.13\%) higher than in 2000. Due to the inability of underdeveloped countries to achieve full employment, but also because of the increased demand for less professional workforce in developed countries and the constant desire for better living conditions, there is a growing number of people in the world who choose to look for happiness abroad. As a result, it is not surprising that $75 \%$ of the world's migrant workers are employed in high-income countries.

The Croatia is estimated to have around 50,000 domestic migrant workers: seafarers - 35,000, construction workers - 10,000 and drivers - 5,000 (Bubas et al., 2013). The number of foreign migrants according to Eurostat in Croatia in 2018 was estimated at 17,400 of which 2,100 refer to EU-27 nationals and 15,300 from countries out of the EU-27. The number of foreigners working in Croatia is modest. It is expected that number to grow in the following period because of flexibilization of the employment of foreigners in the Croatia. 


\section{CONCLUSION}

Between 1967-2019 realistic GDP in the Croatia has increased by 2,43 times or by $143 \%$. During the same period number of employees has increased by $75,4 \%$ which means that the average increase of the GDP by $1 \%$ followed the average growth of the number of employees by $1 \%$. During the period $1967-$ $2019,194,000$ people in average looked for a job each year $(S D=109)$. The highest number of unemployed people was recorded in 2002, when 390,000 people were looking for a job.

The conducted correlation analysis confirmed the existence of a strong correlation between GDP and total employment trends $(\mathrm{r}=0.91 ; \mathrm{p}<0.05)$ as well as a weak and positive correlation between GDP trends and unemployment $(\mathrm{r}=0.29 ; \mathrm{p}<0.05)$. The existence of a positive relationship between GDP and unemployment can be interpreted as structural unemployment. The relationship between GDP and total employment is presented analytically in the form of appropriate regression models. Based on the selected linear model, estimates of the number of employees until 2050 are made with an assumption that an average annual GDP growth rate is $2 \%$.

Based on the forecasts made, Croatia could face a serious problem of labour shortage in the short term. Looked at from a long term perspective and bearing in mind the negative natural and mechanical movement of population, Croatia could face very serious, almost unsolvable problem. In order to achieve positive results, following policies should be carefully designed: demographic, migration, labour, employment, pension and education policy.

\section{ACKNOWLEDGEMENT}

The author, Leszek Kołtun, is grateful for the possibilities of training, provided by co-authors of this article. Gained professional experience and data, collected within training program, allow to contribute to the research.

\section{REFERENCES}

Becic, M., Matic Sosic, M., \& Jasprica, D. (2019). The Role of Precarious Employment in Emigration Flows from Croatia. Montenegrin Journal of Economics, 15(4), 173-182. doi: 10.14254/1800-5845/2019.15-4.13

Bierens, H. J. \& Broersma, L. (1993). The relation between unemployment and interest rate. Econometric Reviews, 12(2), 217-256. https://doi. org/10.1080/07474939308800262

Bilan Y., Mishchuk, H., Roshchyk, I. \& Joshi, O. (2020a). Hiring and retaining skilled employees in SMEs: Problems in human resource practices and links with organizational success. Business: Theory and Practice, 21(2), 780-791. https://doi.org/10.3846/btp.2020.12750

Bilan, Y., Mishchuk, H., Samoliuk, N., \& Mishchuk, V. (2020b). Gender discrimination and its links with compensations and benefits practices in enterprises. Entrepreneurial Business and Economics Review, 8(3), $189-204$. https://doi.org/10.15678/EBER.2020.080311

Bilas, V. (2020). Examining the relationship between foreign direct investment and economic growth: Evidence from Croatia. Montenegrin Journal of Economics, 16(2), 117-129. doi: 10.14254/1800-5845/2020.16-2.9

Bilbao-Ubillos, J., Alsasua, J.L., Intxaurburu, G., \& Ullibarri-Arce, M. (2018). Labour market regulations and high quality employment in EU-15 countries. Innovation: The European Journal of Social Science Research, 31(3), 207226, doi:10.1080/13511610.2017.1384366

Bubas, M., Knezevic, B., Kristo, D., \& Mihalinac-Bolanca, M. (2013). Impact of living and working conditions on the health of migrant workers, Safety, 55(4), 333-339.

Croatian Bureau of Statistics. (2019). https://www.dzs.hr/Hrv_Eng/publication/2019/07-01-01_01_2019.htm $(12.10 .2020)$

Druzic, I. (2004). Resources and Croatian economy markets, Political culture, Zagreb (in Croatian).

ECB (2016). The employment-GDP relationship since the crisis. ECB Economic Bulletin, 6, 53-71. https://www.ecb.europa.eu/pub/pdf/other/eb201606_article01.en.pdf. Eurostat 
Karamanis, K., Beneki, Ch., \& Ioakimidis, M. (2018). Greek labour market: The evaluation of minimum wage and unemployment during the period 2000-2017. Journal of International Studies, 11(4), 93-105. doi:10.14254/20718330.2018/11-4/7

Logarusic, M., \& Raguz Kristic, I. (2019). Determinants of unemployment in the European Union. Economic Review, 70(4) 575-602 (in Croatian).

Maris, M. (2019). Structural and productivity shift of industries in Slovakia and Czech Republic: A comparative study. Journal of International Studies, 12(1), 313-323. doi:10.14254/2071-8330.2019/12-1/21

Mishchuk, H., Bilan, S., Yurchyk, H., Akimova, L., \& Navickas, M. (2020). Impact of the shadow economy on social safety: The experience of Ukraine. Economics and Sociology, 13(2), 284-298.doi:10.14254/2071-789X.2020/132/19

Okun, A.M. (1962). Potential GNP: Its Measurement and Significance. Reprinted as Cowles Foundation Paper, 190, 1-7. https://milescorak.files.wordpress.com/2016/01/okun-potential-gnp-its-measurementand-significancep0190.pdf

Penava, M., \& Druzic, M. (2014). Croatian industrial policy - deindustrialization point of view. Conference Proceedings Development Potentials of Croatian Economy, (ed. Druzić, G. \& Druzić, I.). Faculty of Economics and Business, University of Zagreb, Ed. 1, Vol. 1, chapter 7, 153-173 (in Croatian).

Popovic, G., Eric, O., \& Stanic, S. (2020). Trade openness, institutions and economic growth of the western Balkans countries. Montenegrin Journal of Economics, 16(3), 173-184. doi: 10.14254/1800-5845/2020.16-3.14

Pupavac, D., Delibasic, M., Pupavac, J., \& Streimikis, J. (2020). Interdependence of quality of life and happiness of the population in Southeast European Countries. Montenegrin Journal of Economics, 16(4), 7-15. doi: 10.14254/18005845/2020.16-4.1

Stavytskyy, A., Kharlamova, G., Giedraitis, V., Cheberyako, O., \& Nikytenko, D. (2020). Gender question: Econometric answer. Economics and Sociology, 13(4), 241- 255. doi:10.14254/2071-789X.2020/13-4/15

Stockhammer, E., Guschanski, A., \& Köhler, K. (2014). Unemployment, capital accumulation and labour market institutions in the Great Recession. European Journal of Economics and Economic Policies: Intervention, 11(2), $182-194$. 